\title{
PENGARUH INTELLECTUAL CAPITAL DAN PARTISIPASI ANGGOTA TERHADAP KEBERHASILAN KOPERASI PADA KOPERASI KREDIT BINEKAS CICURUG SUKABUMI
}

\section{THE INFLUENCE OF INTELLECTUAL CAPITAL AND PARTICIPATION OF MEMBERS ON COOPERATIVE'S SUCCESS IN CREDIT COOPERATIVE CICURUG SUKABUMI}

\author{
Irwan $\mathrm{Ch}^{1}$, Siti Jayyidah ${ }^{2}$ \\ Program of Management Study, Faculty of Economics, Djuanda University \\ email : irwan.ch@unida.ac..id; Sitijayyidah@gmail.com;
}

\begin{abstract}
This study aims to analyze the influence of intellectual capital and participation of members on the success of cooperatives in the KOPDIT BINEKAS Cicurug Sukabumi. The object of research is a member of the cooperative. Koesioner was distributed to 100 cooperative member respondents. The research method used is quantitative descriptive and verification. The test conducted is validity test, reliability test, likert scale for multiple linear regression test, correlation coefficient analysis and determination coefficient (R2) which is then tested through $F$ test and t test. The results of the study based on the results of the validity and reliability tests indicate that all instruments on all indicators are declared valid and reliable. Simultaneously, intellectual capital (X1) and member participation (X2) influence the success of cooperatives (Y) on KOPDIT BINEKAS. While partially, all variables have a positive and significant effect on the success of the cooperative (Y) on KOPDIT BINEKAS.
\end{abstract}

Keywords: Intellectual Capital, Member Participation, Cooperative's Success

\begin{abstract}
ABSTRAK
Penelitian ini bertujuan untuk menganalisis pengaruh intellectual capital dan partisipasi anggota terhadap keberhasilan koperasi pada KOPDIT BINEKAS Cicurug Sukabumi. Obyek penelitian adalah anggota koperasi. Koesioner dibagikan kepada 100 responden anggota koperasi. Metode penelitian yang digunakan adalah deskriptif dan verifikatif. Uji yang dilakukan adalah uji validitas, uji reliabilitas, skala likert untuk uji regresi linier berganda, analisis koefisien korelasi dan koefisien determinasi (R2) yang selanjutnya di uji melalui uji $\mathrm{F}$ dan uji t. Hasil penelitian berdasarkan hasil uji validitas dan reliabilitas menunjukkan bahwa semua instrumen pada semua indikator dinyatakan valid dan reliabel. Secara simultan intellectual capital (X1) dan partisipasi anggota (X2) berpengaruh terhadap keberhasilan koperasi (Y) pada KOPDIT BINEKAS. Adapun secara parsial semua variabel berpengaruh positif dan signifikan terhadap keberhasilan koperasi (Y) pada KOPDIT BINEKAS.
\end{abstract}

Kata Kunci : Intellectual Capital, Partisipasi Anggota, Keberhasilan Koperasi 


\section{PENDAHULUAN}

Pembangunan secara nasional saat ini menggunakan pendekatan yang menekankan pada pertumbuhan ekonomi dengan strategi pengembangan industrialisasi dan ekonomi kerakyatan. Kebijakan nasional pembangunan jangka panjang saat ini adalah pelaksanaan otonomi daerah dimana mengarah pada suatu kabupaten atau kota perihal kompetensi. Sesuai dengan isyarat yang ditegaskan dalam UndangUndang No.33/2004 tentang perimbangan keuangan antara pemerintah pusat dan pemerintah daerah bahwa peluang terbesar pengembangan ekonomi ada pada sektor industri yang berbasis lokal.
Seiring berjalannya waktu, koperasi dapat berkembang dengan cukup pesat sehingga mampu menopang perekonomian nasional, maka dari itu dengan adanya koperasi dapat memberikan sumbangan pasar kredit mikro yang tentunya sangat dibutuhkan oleh masyarakat dalam rangka meningkatkan produktivitas. Adapun perekembangan koperasi di Indonesia, tentunya diikuti pula dengan perkembangan jumlah koperasi disemua provinsi yang berjumlah 34 provinsi, salah satunya adalah Provinsi Jawa Barat dengan perkembangan jumlah koperasi terbanyak di Indonesia. Berikut perkembangan Koperasi di Provinsi Jawa Barat dari tahun 2011-2016 :

Tabel 1 Perkembangan Jumlah Koperasi di Jawa Barat Tahun 2010-2016

\begin{tabular}{c|c|c|c}
\hline Tahun & Jumlah Koperasi & Koperasi Aktif & Koperasi Non Aktif \\
\hline 2010 & 22.664 & 14.771 & 7.893 \\
2011 & 23.091 & 14.856 & 8.235 \\
2012 & 24.835 & 15.051 & 9.784 \\
2013 & 25.252 & 15.130 & 10.122 \\
2014 & 25.563 & 15.633 & 9.930 \\
2015 & 25.741 & 16.855 & 8.886 \\
2016 & 25.933 & 16.542 & 9.391 \\
\hline Jumlah & 173.079 & 108.838 & 64.241 \\
Rata- Rata & 24725,57 & 15548,29 & 9177,286 \\
Persentase (\%) & & $\mathbf{6 2 , 8 8}$ & $\mathbf{3 7 , 1 2}$ \\
\hline
\end{tabular}

Sumber: Dinas KUMKM Propinsi Jawa Barat ,2018 (data diolah)

Berdasarkan tabel 1, koperasi terus mengalami peningkatan dari tahun 2011- 2016. Jumlah tertinggi pada tahun 2016 yaitu sebanyak 25.933 koperasi. Seiring dengan pertumbuhan jumlah koperasi terus mengalami kenaikan dan penurunan. Jumlah koperasi yang tidak aktif tertinggi terjadi pada tahun 2013, yaitu menjadi 10.122 Koperasi.

Perkembangan koperasi di Indonesia yang semakin meningkat, diikuti pula dengan perkembangan koperasi diberbagai daerah, khususnya Kabupaten Sukabumi, Jawa Barat. Menurut Kemenkop UKM, Kabupaten Sukabumi sebagai salah satu best practice bagi pengembangan PLUT yang ada. Dimana jumlah koperasi di Kabupaten Sukabumi berdasarkan data UKM, Perdagangan, dan Perindustrian menyebutkan bahwa jumlah koperasi di Kabupaten Sukabumi secara keseluruhan adalah sebanyak 1693 koperasi namun pada tahun 2017 tercatat 314 koperasi, yang aktif melaksanakan kegiatan perkoperasian sebanyak 192 koperasi dan sudah melaksanakan RAT, sisanya 122 koperasi dibubarkan karena tidak aktif melaksanakan kegiatan perkoperasian.

Stewart dalam Usmara (2002: 200) bahwa intellectual capital adalah materi intelektual yang telah diformalisasi, ditangkap dan dimanfaatkan untuk memproduksi aset yang nilainya lebih tinggi. Menurut Hendar dan Kusnandi (2009:34) mengenai pentingnya partisipasi anggota dalam kehidupan koperasi yaitu (perusahaan) yang pemilik dan pelanggan adalah sama, yaitu para anggota dan termasuk prinsip identitas koperasi yang digambarkan dalam tri-angel identity of cooperative, jadi baik itu pelanggan, pemilik, dan anggota ketiga pihak tersebut adalah sama. Dapat dikatakan bahwa berjalan atau tidaknya sukses atau tidaknya koperasi bergantung pada aktif bepartisipasi anggotanya. Menurut Tanjung (2017:117) tolak ukur keberhasilan koperasi salah satunya adalah sangat ditentukan oleh seberapa besar 
partisipasi para anggota dalam memanfaatkan segala fasilitas dari koperasi.

Intellctual capital dan partisipasi anggota merupakan hal yang tidak terpisah dalam keberhasilan usaha suatu koperasi. Tujuan sebuah koperasi untuk mencapai tujuannya yang sudah ditetapkan yaitu mendapatkan keberhasilan dalam menjalankan setiap kegiatannya. Keberhasilan usaha sebuah koperasi dapat dikatakan mengalami perkembangan dalam beberapa waktu melalui operasinya mengalami penigkatan dalam keanggotaan, jenis usaha, volume atau jumlah usaha, manajemen, Sisa Hasil Usaha baik secara kuantitatif dan kualitatif.

Menurut Kusnadi (2009: 236) koperasi kredit merupakan koperasi yang kegiatannya berupa simpan pinjam saja. Keberhasilan KOPDIT BINEKAS diawali dengan pendidikan para anggota, pengurus dan manajemen secara berkelanjutan dengan materi beragam, baik (PDMK) maupun khusus yang dilaksanakan di Pusdiklat Puskopdit Bogor Banten, Cibadak Sukabumi. Keberhasilan KOPDIT BINEKAS yaitu menjadi koperasi dengan tingkat akreditasi terbaik kedua dalam periode tiga tahun berturutturut yakni 2005-2008, kerjasama yang baik dan tingginya rasa memiliki antara anggota, pengurus, pengawas dan manajemen sehingga KOPDITBINEKAS mencapai usia 28 tahun. Jumlah anggota KOPDIT BINEKAS mengalami naik turun dalam delapan tahun terakhir. ditunjukkan oleh tabel 2 berikut :

Tabel 2 Keragaan KOPDIT BINEKAS

\begin{tabular}{ccccccc}
\hline No & Tahun & $\begin{array}{c}\text { Jumlah } \\
\text { Anggota } \\
\text { (orang) }\end{array}$ & $\begin{array}{c}\text { Jumlah Modal } \\
\text { Sendiri (Rp) }\end{array}$ & $\begin{array}{c}\text { Jumlah Modal } \\
\text { Luar (Rp) }\end{array}$ & Jumlah Aset (Rp) & $\begin{array}{c}\text { Jumlah } \\
\text { SHU (Rp) }\end{array}$ \\
\hline 1 & 2010 & 1721 & 1.648 .712 .864 & 1.818 .065 .500 & 4.034 .960 .982 & 20.332 .057 \\
2 & 2011 & 1669 & 1.812 .395 .595 & 2.211 .636 .500 & 4.519 .520 .438 & 36.414 .792 \\
3 & 2012 & 1703 & 1.852 .781 .689 & 2.185 .530 .950 & 4.616 .145 .367 & 17.500 .000 \\
4 & 2013 & 1652 & 1.779 .028 .345 & 2.150 .604 .350 & 4.619 .178 .285 & 34.283 .540 \\
5 & 2014 & 1672 & 1.984 .597 .610 & 2.168 .214 .550 & 4.912 .329 .635 & 23.884 .000 \\
6 & 2015 & 1704 & 2.009 .388 .802 & 2.103 .051 .666 & 5.008 .429 .077 & 57.115 .523 \\
7 & 2016 & 1646 & 2.117 .082 .766 & 2.198 .685 .850 & 4.987 .967 .627 & 20.840 .042 \\
8 & 2017 & 1618 & 2.230 .381 .184 & 2.177 .456 .950 & 5.032 .207 .127 & 9.175 .915 \\
\hline
\end{tabular}

Sumber : Koperasi Simpan Pinjam Bina Ekonomi Keluarga Sejahtera, 2018 (data diolah)

Berdasarkan tabel 1.2 menunjukan bahwa keragaan KOPDIT BINEKAS dengan jumlah anggota tertinggi pada tahun 2010 yaitu sebanyak 1721 anggota, jumlah modal sendiri dalam nominal tertinggi tahun 2017 sebesar Rp2.230.381.184, jumlah modal yang berasal dari luar dalam nominal tertinggi tahun 2011 sebesar Rp2.211.636.500, jumlah aset tertinggi terjadi pada tahun 2017 sebesar Rp5.032.207.127, dan Jumlah SHU tertinggi terjadi pada tahun 2015 dengan nominal sebesar Rp57.115.523.Sehingga keragaan KOPDIT BINEKAS mengalami fluktuasi dari tahun ke tahun hal ini disebabkan karena keikutsertaan dan keaktifan anggota koperasi masih terasa lemah bahkan sebagian anggota ada yang tidak berpartisipasi. Hal tersebut didukung oleh ketua KOPDIT BNEKAS (2018) bahwa kendala yang dihadapi adalah kurangnya tingkat partisipasi anggota, kurangnya pendidikan anggota, masih banyak kredit macet dan anggota lebih banyak meminjam serta tidak membayar daripada simpanan sukarela.

\section{MATERI DAN METODE}

\section{Intellectual Capital}

Ulrich dalam Usmara (2002: 207) memberikan alternatif pengukuran Intellectual Capital dengan komitmen dan kompetensi pekerja dalam melakukan pekerjaannya, dan diformulasikan menjadi intellectual capital = komitmen $\mathrm{x}$ kompetensi. Artinya bahwa perusahaan yang memiliki anggota kompetensi tinggi dan komitmen yang rendah, tidak akan berhasil. Perusahaan dengan anggota berkomitmen tinggi dan kompetensi yang rendah, tidak akan bisa berhasil dengan cepat. Selain itu persamaan diatas adalah perkalian, nilai rendah pada satu faktor menyebabkan intellectual capital secara signifikan.

\section{Partisipasi Anggota}

Menurut Sartika (2013: 97) partisipasi 
anggota merupakan peranan para anggota koperasi selaku pemilik dan pelanggan sangat menentukan jalannya koperasi, tidak hanya dalam pengurusan kepentingan masing-masing anggota dalam pembagian (SHU) saja, melainkan hal-hal yang membutuhkan perhatian lebih banyak dari para anggota guna memajukan atau mempertahankan kondisi usaha koperasi.

\section{Keberhasilan Koperasi}

Menurut Meilani (2002:13) keberhasilan koperasi merupakan prestasi dalam melaksanakan kegiatan berbisnis dalam meningkatkan kesejahteraan anggotanya dan masyarakat pada umumnya. Kriteria Keberhasilan Usaha Koperasi Menurut Alfred Hanel (1985:106) keberhasilan koperasi dapat terlihat dari tiga komponen sebagai berikut:

1. Business Succes, adalah indikator keberhasilan usaha koperasi yang berhubungan dengan keberhasilan bisnis koperasi dalam menjalankan kegiatannya.

2. Member Succes, merupakan keberhasilan koperasi dalam hal meningkatkan jumlah keanggotaannya serta dalam peningkatan kesejahteraan setiap anggotanya.

3. Development Succes, merupakan keberhasilan koperasi dalam hal kontribusinya terhadap pembangunan dan lingkungan sekitar.

\section{Koperasi}

Menurut Undang-undang Koperasi Indonesia No. 25 Tahun 1992 mendefinisikan bahwa koperasi adalah badan usaha yang beranggotakan seorang atau badan hukum koperasi, melandaskan kegiatannya berdasarkan prinsip koperasi dan sebagai gerakan ekonomi rakyat, yang berdasarkan atas azas kekeluargaan.

\section{Koperasi Kredit}

Peraturan Pemerintah Nomor 9 Tahun 1995 pasal1 bahwa Koperasi Kredit yang kegiatannya adalah usaha simpan pinjam. Prinsip keanggotaannya bebas bagi semua orang untuk menjadi anggota koperasi dan mempuyai usaha atau kepentingan ekonomi yang sama. ( Hendar dan Kusnadi, 2009: 236).

\section{Hipotesis Penelitian}

Berdasarkan pada latar belakang masalah yang telah di jelaskan sebelumnya, maka hipotesis yang dapat di kembangkan adalah sebagai berikut :

$\mathrm{H}_{1}$ : Terdapat pengaruh positif dan signifikan Intellectual Capital terhadap keberhasilan koperasi.

$\mathrm{H}_{2}$ : Terdapat pengaruh positif dan signifikan partisipasi anggota terhadap keberhasilan koperasi.

$\mathrm{H}_{3}$ :Terdapat pengaruh positif dan signifikan intellectual capital dan partisipasi anggota terhadap keberhasilan usaha koperasi

\section{Variabel Penelitian}

Variabel independen disini adalah intellectual capital dan partisipasi anggota sedangkan Variabel dependen disini adalah keberhasilan koperasi. Hubungan antar variabel penelitian dapat diungkapkan dalam model sebagai berikut :

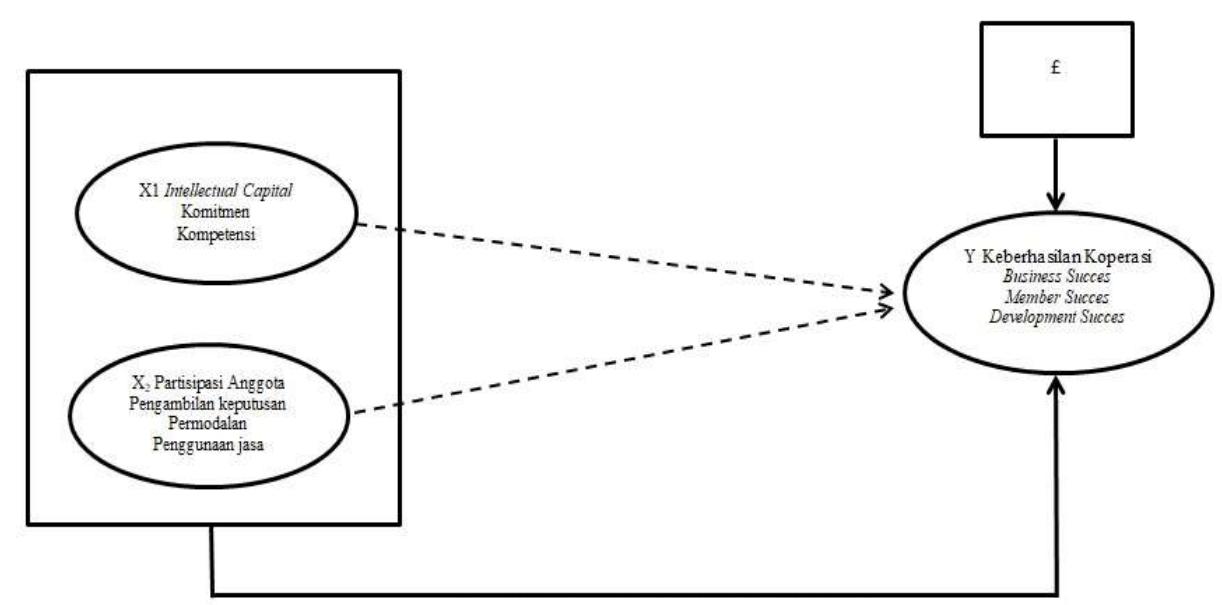

Gambar : 1 Hubungan Antara Variabel Penelitian 
Keterangan :

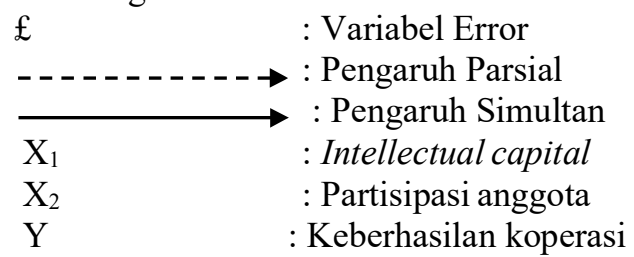

\section{Operasionalisasi Variabel}

Variabel yang diteliti pada penelitian ini adalah Intellectual capital $\left(\mathrm{X}_{1}\right)$, Partisipasi Anggota $\left(\mathrm{X}_{2}\right)$ dan Keberhasilan Koperasi(Y) sebagai berikut :

\begin{tabular}{|c|c|c|c|c|}
\hline Variabel & Konsep Variabel & Indikator & $\begin{array}{l}\text { Skala } \\
\text { Ukur }\end{array}$ & Sumber \\
\hline $\begin{array}{l}\text { Intellectual } \\
\text { Capital }\left(\mathrm{X}_{1}\right)\end{array}$ & $\begin{array}{l}\text { Materi intelektual yang } \\
\text { diformalisasi, telah } \\
\text { dimanfaatkan untuk memproduksi aset } \\
\text { yang nilainya lebih tinggi. Setiap } \\
\text { organisasi menempatkan materi } \\
\text { intelektual dalam bentuk aset sumber } \\
\text { daya, perspektif dan kemampuhan } \\
\text { eksplisit dan tersembunyi, data, informasi, } \\
\text { pengetahuan dan mungkin kebijakan }\end{array}$ & $\begin{array}{l}\text { 1. Komitmen } \\
\text { 2. Kompetensi }\end{array}$ & $\begin{array}{l}\text { Ordinal } \\
\text { Likert } \\
(1-5)\end{array}$ & $\begin{array}{l}\text { Ulrch } \\
\text { dalam } \\
\text { Usmara } \\
(2000: 207)\end{array}$ \\
\hline $\begin{array}{l}\text { Partisipasi } \\
\text { Anggota }\left(\mathrm{X}_{2}\right)\end{array}$ & $\begin{array}{l}\text { Merupakan peranan para } \\
\text { anggota koperasi selaku pemilik dan } \\
\text { pelanggan sangat menentukan jalannya } \\
\text { koperasi, tidak hanya dalam pengurusan } \\
\text { kepentingan masing- masing anggota } \\
\text { dalam pembagian SHU saja, melainkan } \\
\text { hal- hal yang membutuhkan perhatian } \\
\text { lebih banyak dari para anggota guna } \\
\text { memajukan atau mempertahankan kondisi } \\
\text { usaha koperasi. }\end{array}$ & $\begin{array}{l}\text { 1. Partisipasi } \\
\text { Pengambilan } \\
\text { Keputusan dalam } \\
\text { Rapat Anggota } \\
\text { 2. Partisipasi dalam } \\
\text { Permodalan } \\
\text { 3. Partisipasi dalam } \\
\text { menggunakan jasa } \\
\text { koperasi }\end{array}$ & $\begin{array}{l}\text { Ordinal } \\
\text { Likert }\end{array}$ & $\begin{array}{l}\text { Sartika } \\
(2013: 97) ; \\
\text { Anoraga } \\
\text { dan } \\
\text { Widiyanti } \\
(2003: 15) \\
\text { Tohar } \\
(2000: 19)\end{array}$ \\
\hline $\begin{array}{l}\text { Keberhasilan } \\
\text { Koperasi(Y) }\end{array}$ & $\begin{array}{l}\text { Merupakan prestasi dalam melaksanakan } \\
\text { kegiatan berbisnis dalam meningkatkan } \\
\text { kesejahteraan anggota dan masyarakat } \\
\text { pada umumnya. }\end{array}$ & $\begin{array}{l}\text { 1. Business Succes } \\
\text { 2. Member Succes } \\
\text { 3. Development } \\
\text { Succes }\end{array}$ & $\begin{array}{l}\text { Ordinal } \\
\text { Likert }\end{array}$ & $\begin{array}{l}\text { Meilani } \\
(2002: 13) ; \\
\text { Hanel } \\
(1989: 106)\end{array}$ \\
\hline
\end{tabular}

\section{Populasi dan Sampel Penelitian}

Arikunto (2014:13) menyatakan bahwa populasi adalah sekumpulan objek yang mempunyai karakter yang sama, populasi terdiri dari objek atau subjek yang mempunyai karakteristik tertentu yang mempunyai kesempatan sama untuk menjadi anggota sampel. Sampel adalah bagian dan karakteristik yang dimiliki oleh populasi tersebut (Sugiyono, 2017:215). Teknik pengambilan sampel berikut : Ukuran sampel anggota ditentukan berdasarkan rumus solvin dari Sugiyono (2017:87), sebagai berikut:

$$
\mathbf{n}=\frac{\mathrm{N}}{\mathrm{Nd}^{2}+\mathbf{1}}
$$

\section{Keterangan :}

$\mathrm{n}:$ Jumlah sampel minimal

$\mathrm{N}$ : Ukuran populasi atau jumlah seluruh anggota koperasi

D : Presisi yang digunakan $10 \%$

Berdasarkan data dari KOPDIT

BINEKAS Cicurug Sukabumi, bahwa jumlah anggota aktif di tahun terakhir adalah sebanyak 1618 orang. Sehingga diperoleh jumlah responden yaitu:

$$
\begin{aligned}
& \mathrm{n}=\underline{1618} \times\left(1618 \times 0,1^{2}\right)+1 \\
& \mathrm{n}=94,179 \text { dibulatkan menjadi } 100
\end{aligned}
$$

Jadi sampel yang akan diambil adalah 100 responden.

Responden yang dipilih berjumlah 100 
yang ditujukan kepada anggota KOPDIT BINEKAS. Hal ini dilakukan karena objek penelitian relative bersifat homogen.

\section{Metode Pengujian Instrumen}

Uji validitas digunakan untuk mengukur valid tidaknya suatu Kuesioner (Sugiyono, 2014:203). Batas koefisien korelasi dinyatakan valid minimal 0,3 sedangkan item yang memiliki korelasi $\geq 0,3$ tidak valid.

Suatu kuesioner dikatakan handal jika jawaban pertanyaan adalah stabil. Instrumen yang reliabel bila digunakan beberapa kali untuk mengukur obyek yang sama akan menghasilkan data yang sama (Sugiyono, 2014:203). Dalam penelitian ini menggunakan teknik cronbach alpha. Dengan criteria bahwa instrument dikatakan riliabel apabila angka conbach alpha lebih besar dari 0,6.

\section{Metode Analisis}

Untuk menganalisis data penelitian ini menggunakan regresi berganda, menurut Sugiyono (2005:211) untuk meramalkan pengaruh dua variabel bebas atau lebih terhadap satu variabel terikat. Model hubungan intellctual capital dan partisipasi anggota terhadap keberhasilan koperasi disusun dalam fungsi atau persamaan sebagai berikut :

$$
\begin{aligned}
& \mathbf{Y}=\mathbf{a}+\boldsymbol{\beta}_{\mathbf{1}} \mathbf{X}_{\mathbf{1}}+\boldsymbol{\beta}_{\mathbf{2}} \mathbf{X}_{\mathbf{2}}+\mathbf{e} \\
& \text { Keterangan : } \\
& \mathrm{Y}=\text { Variabel terikat } \\
& \mathrm{X}=\text { Variabel bebas } \\
& \mathrm{a}=\text { Konstanta } \\
& \beta_{1}= \text { Koefisien regresi untuk mengetahui } \\
& \text { pengaruh faktor intellctual capital } \\
& \text { terhadap keberhasilan koperasi } \\
& \beta_{2}= \text { Koefisien regresi untuk mengetahui } \\
& \text { pengaruh faktor partisipasi anggota } \\
& \text { terhadap keberhasilan koperasi }
\end{aligned}
$$

Analisis ini dilakukan untuk mengukur kuat atau tidaknya hubungan antara intellctual capital dan partisipasi anggota terhadap keberhasilan koperasi. Adapun interpretasinya sebagai berikut :

a) Apabila $\mathrm{r}=0$ atau mendekati 0 , artinya hubungan kedua variabel sangat rendah.

b) Apabila $\mathrm{r}=1$ atau mendekati 1 , maka hubungan kedua variabel bersifat searah dan sangat kuat, artinya kenaikan nilai-nilai $X$ akan diikuti oleh kenaikan nilai-nilai $\mathrm{Y}$, atau sebaliknya.

c) Apabila $\mathrm{r}=-1$ atau mendekati -1 , maka hubungan antara kedua variabel berlawanan arah dan sangat kuat, artinya kenaikan nilainilai $\mathrm{X}$ diikuti penurunan nilai-nilai $\mathrm{Y}$, atau sebaliknya.

Tabel 4 Interpretasi Terhadap Nilai r Hasil

\begin{tabular}{cc}
\hline Interval Nilai $\mathbf{r}$ & Interpretasi \\
\hline $0,00-0,199$ & Sangar Rendah \\
$0,20-0,399$ & Rendah \\
$0,40-0,599$ & Sedang \\
$0,60-0,799$ & Kuat \\
$0,80-0,1000$ & Sangat Kuat \\
\hline
\end{tabular}

Sumber : Sugiyono, (2017:184)

\section{Pengujian Hipotesis}

Pengujian hipotesis dilakukan untuk melihat apakah variabel bebas mampu menjelaskan tingkah laku variabel terikat. Adapun pengujian ini mengunakan $\alpha 5 \%$ atau 0,05 (Suharyadi dan Purwanto, 2009 : 225). Maka diperlukan pengujian hipotesis nol $\left(\mathrm{H}_{\mathrm{o}}\right)$ dan hipotesis alternative $\left(\mathrm{H}_{\mathrm{a}}\right)$. Maka digunakan uji $\mathrm{F}$ dan uji t.

\section{HASIL DAN PEMBAHASAN}

\section{Instrument Penelitian}

Hasil uji validitas menunjukkan bahwa seluruh instrument dalam penelitian ini dikatakan valid jika nilai $r$ hitung lebih dari 0,3 . Artinya semua instrumen dapat digunakan dalam penelitian. Sedangkan hasil uji reliabilitas penelitian ini bahwa semua variabel dikatakan reliabel karena memiliki nilai $r$ hitung lebih dari 0,6 . Artinya semua variabel dalam penelitian ini dapat dipercaya dan dapat dijadikan sebagai bahan penelitian.

\section{Karakteristik Responden}

Karakteristik responden mayoritas anggota (KOPDIT BINEKAS) adalah perempuan dengan jumlah 61 orang atau sebesar $61 \%$ dimana usia anggota 31-40 tahun dengan jumlah 35 orang atau sebesar $35 \%$. Adapun tingkat pendidikan anggota adalah SMA dengan jumlah 48 orang atau $48 \%$ dan lama menjadi anggota $<5$ tahun dengan jumlah 50 orang atau sebesar $50 \%$ dengan jumlah pendapatan perbulan Rp500.000Rp3.000.000 dengan jumlah 41 orang atau sebesar $41 \%$.

\section{Tanggapan Responden Intellectual Capital}

Tanggapan responden terkait intellectual capital 
dilihat pada tabel berikut:

Tabel 5 Rekapitulasi Penilaian Anggota Koperasi

Terhadap Kondisi Intellectual Capital ( X )

\begin{tabular}{|c|c|c|c|c|}
\hline No & Uraian & Nilai & Kriteria & Interpretasi \\
\hline 1 & Loyalitas anggota koperasi & 4,38 & $\begin{array}{l}\text { Sangat } \\
\text { baik }\end{array}$ & $\begin{array}{l}\text { Kecintaan anggota untuk tetap bertahan di } \\
\text { koperasi. }\end{array}$ \\
\hline 2 & $\begin{array}{l}\text { Bangga menjadi anggota } \\
\text { koperasi }\end{array}$ & 4,12 & Baik & Memiliki rasa suka duka terhadap koperasi \\
\hline 3 & $\begin{array}{l}\text { Tanggung jawab anggota } \\
\text { koperasi }\end{array}$ & 4,04 & Baik & $\begin{array}{l}\text { Kesediaan anggota untuk menerima } \\
\text { tanggung jawab yang lebih besar. }\end{array}$ \\
\hline 4 & $\begin{array}{l}\text { Kepercayaan anggota } \\
\text { koperasi }\end{array}$ & 4,34 & $\begin{array}{l}\text { Sangat } \\
\text { baik }\end{array}$ & $\begin{array}{l}\text { Kepercayaan anggota terhadap koperasi } \\
\text { terjalin melalui komunikasi dan informasi } \\
\text { yang akurat }\end{array}$ \\
\hline 5 & Mendapatkan reward & 4,13 & Baik & $\begin{array}{l}\text { Bentuk penghargaan kepada anggota } \\
\text { terbaik dalam periode satu tahun yang di } \\
\text { umumkan pada saat RAT berlangsung } \\
\text { dengan tujan untuk memotivasi anggota } \\
\text { lain agar menjadi lebih baik di periode } \\
\text { berikutnya. }\end{array}$ \\
\hline 6 & Memiliki rasa percaya diri & 4,29 & $\begin{array}{l}\text { Sangat } \\
\text { baik }\end{array}$ & $\begin{array}{l}\text { Rasa percaya diri anggota muncul jika } \\
\text { tidak mempunyai ketergantukan akan suatu } \\
\text { hal serta adanya perasaan kompeten atau } \\
\text { merasa dirinya mampu akan sesuatu. }\end{array}$ \\
\hline \multirow[t]{2}{*}{7} & $\begin{array}{l}\text { Memiliki keterampilan } \\
\text { tertentu }\end{array}$ & 4,06 & Baik & $\begin{array}{l}\text { Dengan memiliki keterampilan tertentu } \\
\text { baik yang berasal dari ide sendiri akan } \\
\text { menghasilkan daya jual yang bersaing. }\end{array}$ \\
\hline & $\begin{array}{l}\text { Profesionalisme dan } \\
\text { keterampilan manajerial }\end{array}$ & 4,21 & $\begin{array}{l}\text { Sangat } \\
\text { baik }\end{array}$ & $\begin{array}{l}\text { Manajemen koperasi yang } \\
\text { professional }\end{array}$ \\
\hline \multicolumn{2}{|c|}{$\begin{array}{l}\text { Rata- rata penilaian anggota } \\
\text { terhadap Intellectual Capital }\left(\mathrm{X}_{1}\right)\end{array}$} & 4,19 & Baik & Memiliki Intellectual Capital yang baik \\
\hline
\end{tabular}

Sumber : Data diolah, 2018

Berdasarkan tabel 5 hasil dari rekapitulasi menyatakan bahwa nilai rata-rata terendah pada penilaian anggota koperasi adalah 4,04 pada instrumen tanggung jawab anggota koperasi dan nilai rata-rata tertinggi yaitu 4,38 pada instrumen loyalitas anggota koperasi, sedangkan rata-rata rekapitulasi penilaian anggota koperasi terhadap intellectual capital adalah 4,19 termasuk dalam kategori Baik, bahwa intellectual capital merupakan hal penting dalam mencapai suatu keberhasilan koperasi. Adanya pengungkapan intellectual capital tidak langsung diharapkan dapat mendorong perusahaan yang nantinya berpengaruh terhadap keputusan investor. knowledge capital atau intellectual capital berperan sangat penting di perusahaan. Perusahaan sebagai salah satu bentuk organisasi pada umumnya memiliki tujuan (Pasaribu dkk, 2014: 152)

Tanggapan responden terkait partisipasi anggota dilihat pada tabel berikut: 
Tabel 6 : Rekapitulasi Penilaian Anggota Koperasi Terhadap Kondisi Partisipasi Anggota $\left(\mathrm{X}_{2}\right)$

\begin{tabular}{|c|c|c|c|c|}
\hline No & Uraian & Nilai & Kriteria & Interpretasi \\
\hline 1 & $\begin{array}{l}\text { Menghadiri Rapat Anggota } \\
\text { Tahunan (RAT) }\end{array}$ & 4,38 & $\begin{array}{c}\text { Sangat } \\
\text { baik }\end{array}$ & $\begin{array}{l}\text { Tingkat kehadiran anggota koperasi pada saat } \\
\text { RAT sangat baik, yaitu lebih dari } 85 \% \text { hal ini } \\
\text { menunjukan bahwa peran anggota sangat } \\
\text { penting }\end{array}$ \\
\hline 2 & Menyampaikan pendapat & 4,31 & $\begin{array}{l}\text { Sangat } \\
\text { baik }\end{array}$ & $\begin{array}{l}\text { Partisipasi anggota dalam menyampaikan } \\
\text { pendapat dan saran dalam RAT sudah sangat } \\
\text { baik, yaitu sebesar } 85 \% \text {. Sehingga, pendapat } \\
\text { dan saran sangat penting untuk membangun } \\
\text { koperasi }\end{array}$ \\
\hline 3 & $\begin{array}{l}\text { Ikut serta dalam pegambilan } \\
\text { keputusan }\end{array}$ & 4,05 & Baik & $\begin{array}{l}\text { Anggota sudah berpartisipasi dengan baik, } \\
\text { karena anggota menyadari hak dan perannya. }\end{array}$ \\
\hline 4 & $\begin{array}{l}\text { Bersedia membayar simpanan } \\
\text { pokok, simpanan wajib dan } \\
\text { simpanan sukarela }\end{array}$ & 4,16 & Baik & $\begin{array}{l}\text { Partisipasi anggota dalam membayar } \\
\text { simpanan pokok, simpanan wajib dan sukarela } \\
\text { berada pada kategoi baik, yaitu sebanyak } 60 \% \\
\text { anggota, menunjukan bahwa anggota } \\
\text { memahami kewajibannya, walaupun belum } \\
\text { sepenuhnya karena masih ada yang lalai. }\end{array}$ \\
\hline 5 & Turut serta dalam permodalan & 4,16 & Baik & $\begin{array}{l}\text { Sebanyak } 60 \% \text { anggota koperasi berpartisipasi } \\
\text { dengan baik dalam hal permodalan, hanya saja } \\
\text { belum sepenuhnya sehingga modal koperasi } \\
\text { mengalami penurunan. }\end{array}$ \\
\hline 6 & Menabung di koperasi & 4,11 & Baik & $\begin{array}{l}\text { Dengan menabung dikoperasi maka anggota } \\
\text { telah percaya dengan baik terhadap } \\
\text { pengelolaan uang di koperasi. }\end{array}$ \\
\hline 7 & Menjadi pelanggan koperasi & 4,17 & Baik & $\begin{array}{l}\text { Sebanyak } 80 \% \text { anggota koperasi sudah } \\
\text { memanfaatkan toko koperasi yang disediakan } \\
\text { untuk membeli dan memenuhi kebutuhannya. }\end{array}$ \\
\hline 8 & $\begin{array}{l}\text { Memanfaatkan fasilitas } \\
\text { koperasi }\end{array}$ & 4,06 & Baik & $\begin{array}{l}\text { Anggota koperasi memanfaatkan fasilitas } \\
\text { dengan baik. }\end{array}$ \\
\hline 9 & $\begin{array}{l}\text { Mengikuti perkembanga } \\
\text { usaha koperasi }\end{array}$ & 4,22 & $\begin{array}{l}\text { Sangat } \\
\text { baik }\end{array}$ & $\begin{array}{l}\text { Perkembagan usaha koperasi selalu diikuti } \\
\text { oleh anggota, yaitu sebesar } 90 \% \text { menunjukan } \\
\text { bahwa anggota memiliki kesadaran yang } \\
\text { tinggi untuk mengikuti perkembangan usaha }\end{array}$ \\
\hline \multicolumn{2}{|c|}{$\begin{array}{l}\text { Rata rata penilaian anggota } \\
\text { terhadap partisipasi anggota }(\mathrm{X} 2)\end{array}$} & 4,18 & Baik & $\begin{array}{l}\text { Partisipasi anggota yang dilakukan pada } \\
\text { koperasi sudah berjalan baik hanya saja } \\
\text { belum optimal sehingga kedepan perlu } \\
\text { adanya perbaikan. }\end{array}$ \\
\hline
\end{tabular}

Sumber : Data diolah, 2018

Berdasarkan tabel 6 hasil dari rekapitulasi menyatakan bahwa nilai rata-rata terendah pada penilaian anggota koperasi adalah 4,05 pada instrumen Ikut serta dalam pengambilan keaputusan dan nilai rata-rata tertinggi yaitu 4,38 pada instrumen menghadiri RAT Sedangkan rata-rata rekapitulasi penilaian anggota koperasi terhadap partisipasi anggota adalah 4,18. Termasuk kategori Baik bahwa partisipasi anggota salah satu hal penting dalam mencapai suatu keberhasilan koperasi. Partisipasi anggota diukur dari kesediaan anggota untuk menjalankan kewajiban dan hak keanggotaanya dengan tanggung jawab, sehingga dikatakan baik dan sebaliknya. (Anoraga \& Widiyanti, 2003:111). 
Tanggapan responden terkait keberhasilan koperasi dapat dilihat pada tabel berikut:

Tabel 7 : Rekapitulasi Penilaian Anggota terhadap Keberhasilan Koperasi

\begin{tabular}{|c|c|c|c|c|}
\hline No & Uraian & Nilai & Kriteria & Interpretasi \\
\hline 1 & $\begin{array}{l}\text { Sisa Hasil Usaha (SHU) } \\
\text { meningkat }\end{array}$ & 3,99 & Tinggi & $\begin{array}{l}\text { Peningkatan SHU yang diterima oleh } \\
\text { koperasi termasuk kategori tinggi, } \\
\text { menunjukan bahwa pengelolaan koperasi } \\
\text { sudah berjalan dengan efektif. }\end{array}$ \\
\hline 2 & $\begin{array}{l}\text { Sisa Hasil Usaha (SHU) } \\
\text { yang diberikan tepat waktu }\end{array}$ & 3,99 & Tinggi & $\begin{array}{l}\text { Ketepatan pembagian SHU pada saat } \\
\text { RAT menumbuhkan kepercayaan } \\
\text { anggota terhadap koperasi. }\end{array}$ \\
\hline 3 & $\begin{array}{l}\text { Pembangian Sisa Hasil } \\
\text { Usaha (SHU) } \\
\text { dilakukan secara adil }\end{array}$ & 3,99 & Tinggi & $\begin{array}{l}\text { Koperasi telah memenuhi kewajibannya } \\
\text { dengan sangat baik untuk memberikan } \\
\text { hak anggota secara adil, yaitu SHU dari } \\
\text { setiap kegiatan koperasi. }\end{array}$ \\
\hline 4 & Aktif membayar simpanan & 4,16 & Tinggi & $\begin{array}{l}\text { Anggota koperasi aktif dalam membayar } \\
\text { simpanan pokok, simpanan wajib dan } \\
\text { sukarela untuk membantu dalam } \\
\text { perputaran modal koperasi. }\end{array}$ \\
\hline 5 & $\begin{array}{l}\text { Koperasi memperoleh dana } \\
\text { hibah }\end{array}$ & 4,01 & Tinggi & $\begin{array}{l}\text { Koperasi mendapat dukungan dari } \\
\text { pemerintah }\end{array}$ \\
\hline 6 & $\begin{array}{l}\text { Barang yang dijual } \\
\text { semakin bervariasi }\end{array}$ & 3,97 & Tinggi & $\begin{array}{l}\text { Koperasi telah menyediakan pelayanan } \\
\text { jasa untuk membantu menyediakan } \\
\text { kebutuhan pokok yang dapat } \\
\text { dimanfaatkan oleh anggota dan } \\
\text { masyarakat seperti pembayaran listrik, } \\
\text { pulsa, tiket pesawat dan kereta serta } \\
\text { tabung gas. }\end{array}$ \\
\hline 7 & $\begin{array}{l}\text { Jumlah anggota koperasi } \\
\text { semakin bertambah }\end{array}$ & 4,22 & $\begin{array}{l}\text { Sangat } \\
\text { tinggi }\end{array}$ & $\begin{array}{l}\text { Peningkatan jumlah anggota tertinggi } \\
\text { pada tahun } 2015 \text { sebesar } 12,73 \% \text { dan } \\
\text { pada tahun } 2017 \text { menurun menjadi } \\
12,08 \% \text {. Tetapi sesuai dengan pernyataan } \\
\text { Dinas Koperasi dan UMKM Kabupaten } \\
\text { Sukabumi (2018)bahwa jika } \\
\text { dibandingkan dengan koperasi lain di } \\
\text { kabupaten sukabumi KOPDIT BINEKAS } \\
\text { termasuk dalam kategori sangat baik, hal } \\
\text { ini terbukti dengan pencapaian KOPDIT } \\
\text { BINEKAS dengan akreditasi terbaik } \\
\text { selama tiga tahun berturut- turut. }\end{array}$ \\
\hline 8 & $\begin{array}{l}\text { Melalui Sisa Hasil Usaha } \\
\text { (SHU) dapat meningkatkan } \\
\text { pendapatan dalam } \\
\text { memenuhi kebutuhan }\end{array}$ & 3,89 & Tinggi & $\begin{array}{l}\text { Memenuhi kebutuhan hidup dengan } \\
\text { SHU yang diperoleh }\end{array}$ \\
\hline 9 & $\begin{array}{l}\text { Koperasi memberikan } \\
\text { tunjangan kesehatan }\end{array}$ & 3,98 & Tinggi & $\begin{array}{l}\text { anggota menyatakan } \\
\text { kebutuhan yang berkaitan dengan } \\
\text { tunjangan kesehatan sudah terpenuhi, } \\
\text { menunjukan bahwa koperasi sangat } \\
\text { memperhatiakn kondisi kesehatan } \\
\text { anggota }\end{array}$ \\
\hline
\end{tabular}




\begin{tabular}{|c|c|c|c|c|}
\hline No & Uraian & Nilai & Kriteria & Interpretasi \\
\hline 10 & $\begin{array}{l}\text { Koperasi dapat } \\
\text { mengalokasikan dana } \\
\text { sosial }\end{array}$ & 4,13 & Tinggi & $\begin{array}{l}\text { Koperasi sudah berkontribusi dengan } \\
\text { tinggi terhadap lingkungan sekitar, } \\
\text { dengan mengalokasikan dana sosial } \\
\text { sebesar 2,50\% dari SHU. Bantuan yang } \\
\text { telah dilakukan oleh koperasi diantaranya } \\
\text { santunan anak yatim dan jompo. }\end{array}$ \\
\hline 11 & $\begin{array}{l}\text { Koperasi dapat membantu } \\
\text { pembangunan fisik daerah } \\
\text { sekitar }\end{array}$ & 4,04 & Tinggi & $\begin{array}{l}\text { Koperasi sudah berkontribusi dengan } \\
\text { tinggi terhadap lingkungan sekitar, } \\
\text { dengan mengalokasikan dana untuk } \\
\text { pembangunan fisik daerah sekitar sebesar } \\
2,50 \% \text { dari SHU. Bantuan yang telah } \\
\text { dilakukan oleh koperasi diantaranya } \\
\text { dalam pembangunan jalan dan sarana } \\
\text { ibadah. }\end{array}$ \\
\hline 12 & $\begin{array}{l}\text { Anggota dapat belajar } \\
\text { untuk hidup demokratis }\end{array}$ & 4,23 & $\begin{array}{l}\text { Sangat } \\
\text { tinggi }\end{array}$ & $\begin{array}{l}\text { Anggota mampu berfikir kritis yang } \\
\text { dapat dibuktikan pada saat penyampaian } \\
\text { kritik dan saran pada saat RAT } \\
\text { berlangsung. }\end{array}$ \\
\hline 13 & $\begin{array}{l}\text { Koperasi } \text { berkontribusi } \\
\text { kepada pengusaha kecil } \\
\text { dengan membentuk } \\
\text { jaringan kerja }\end{array}$ & 4,26 & $\begin{array}{l}\text { Sangat } \\
\text { tinggi }\end{array}$ & $\begin{array}{l}\text { Kontribusi koperasi kepada masyarakat } \\
\text { sekitar yang memiliki usaha sudah sangat } \\
\text { tinggi, koperasi memberikan akses } \\
\text { jaringan kerja yang dapat dimanfaatkan } \\
\text { oleh pengusaha kecil. }\end{array}$ \\
\hline 14 & $\begin{array}{l}\text { Besarnya } \quad \text { pendapatan } \\
\text { koperasi } \\
\text { pada pendapatan daerah }\end{array}$ & 4,04 & Tinggi & Koperasi membantu program pemerintah \\
\hline \multicolumn{2}{|c|}{$\begin{array}{l}\text { Rata- rata penilaian anggota } \\
\text { terhadap keberhasilan koperasi } \\
\text { (Y) }\end{array}$} & 4,06 & Tinggi & $\begin{array}{l}\text { Keberhasilan usaha yang dicapai } \\
\text { koperasi sudah tinggi, ini ditunjukan } \\
\text { dengan rata-rata } 80 \% \text { program-program } \\
\text { koperasi sudah tercapai sesuai dengan } \\
\text { buku agenda kegiatan koperasi. Dalam } \\
\text { hal ini peran anggota dan koperasi sudah } \\
\text { berjalan dengan baik dalam mendukung } \\
\text { setiap kegiatan usaha koperasi. }\end{array}$ \\
\hline
\end{tabular}

Sumber : Data diolah, 2018

Berdasarkan tabel 7 hasil dari rekapitulasi menyatakan bahwa nilai rata-rata terendah pada penilaian anggota koperasi adalah 3,89 pada instrumen melalui (SHU) dapat meningkatkan pendapatan dalam memenuhi kebutuhan dan nilai rata-rata tertinggi yaitu 4,26 pada instrumen Koperasi berkontribusi kepada pengusaha kecil dengan membentuk jaringan kerja. Sedangkan rata- rata rekapitulasi penilaian anggota koperasi terhadap keberhasilan koperasi adalah 4,06. Penilaian ini masuk dalam kategori Tinggi. Menurut Fathorrazi (2004 : 35) Keberhasilan koperasi tidak hanya pada keberhasilan dalam segi bisnis semata, melainkan keberhasilan tersebut harus berimbas pada peningkatan kemanfaatan bagi anggotanya.

\section{Hasil Estimasi Persamaan Regresi}

Dihitung dengan menggunakan analisis regresi berganda. Adapun ringkasan perhitungan data hasil penelitian disajikan berikut : 
Tabel 8 Koefisien Regresi dan Uji Signifikasi Coeficients

\begin{tabular}{|c|c|c|c|c|c|}
\hline \multirow[b]{2}{*}{ Model } & \multicolumn{2}{|c|}{$\begin{array}{c}\text { Unstandardized } \\
\text { Coefficients } \\
\end{array}$} & \multirow{2}{*}{$\begin{array}{c}\begin{array}{c}\text { Standardized } \\
\text { Coefficients }\end{array} \\
\text { Beta } \\
\end{array}$} & \multirow[b]{2}{*}{$\mathrm{t}$} & \multirow[b]{2}{*}{ Sig. } \\
\hline & $\mathrm{B}$ & Std. Error & & & \\
\hline 1 (Constant) & 1.792 & 5.638 & & .318 & .751 \\
\hline Intellectual Capital $\mathrm{X}_{1}$ & 1.060 & .229 & .438 & 4.634 & .000 \\
\hline Partisipas Anggota $\mathrm{X}_{2}$ & .611 & .158 & .366 & 3.869 & .000 \\
\hline
\end{tabular}

Dependent Variable: Y (Keberhasilan Koperasi)

Sumber : Data primer diolah, 2018

Berdasarkan tabel 8 tersebut maka diperoleh suatu persamaan regresi dengan model taksiran berikut :

$$
Y=1,792+1,060 X_{1}+0,611 X_{2}+\varepsilon
$$

Hasil tersebut dapat diinterpretasikan sebagai berikut :

1. Konstanta (a) sebesar 1,792 artinya pada saat Intellectual Capital dan Partisipasi Anggota $\left(\mathrm{X}_{1}\right.$ dan $\mathrm{X}_{2}=0$ ) maka keberhasilan koperasi sebesar 1,792

keberhasilan koperasi (Y) dan $\mathrm{X}_{2}$ tetap.

3. Koefisien regresi partisipasi anggota $\left(X_{2}\right)=0,611$ artinya setiap terjadi kenaikan partisipasi anggota akan diikuti dengan kenaikan keberhasilan koperasi (Y) dan $\mathrm{X}_{1}$ tetap.

\section{Pengujian Koefisien Determinasi}

Besarnya pengaruh variabel faktor intellectual capital dan partisipasi anggota terhadap keberhasilan koperasi

2. Koefisien regresi intellectual capital $\left(\mathrm{X}_{1}\right)=1,060$ ątirrya simpuptan dapat dilihat dari $\mathrm{R}$ terjadi kenaikan intellectual capital akan diikuti dengan kenaikan

Tabel 9 Pengujian Koefisien Determinasi

\begin{tabular}{|c|c|c|c|c|}
\hline Model & $\mathrm{R}$ & R Square & Adjusted R Square & $\begin{array}{c}\text { Std. Error of the } \\
\text { Estimate }\end{array}$ \\
\hline 1 & $.739^{\mathrm{a}}$ & .546 & .537 & 4.915 \\
\hline
\end{tabular}

a. Predictors: (Constant), partisipasi anggota $\left(\mathrm{X}_{2}\right)$ Intellectual capital $\left(\mathrm{X}_{1}\right)$

b. Dependent Variable: Y

Sumber data primer diolah, 2018

Berdasarkan tabel 9 maka diperoleh hubungan antara intellectual capital dan partisipasi anggota terhadap keberhasilan (KOPDIT BINEKAS) menunjukan angka korelasi 0,739 berada pada kategori kuat. Artinya bahwa semakin tinggi intellectual capital dan partisipasi anggota maka keberhasilan koperasi pada (KOPDIT BINEKAS) semakin meningkat pula. Adapun nilai dari $\mathrm{R}$ square 0,546 atau $54,6 \%$. Hal ini menunjukan bahwa persentase sumbangan pengaruh variabel antara intellectual capital $\left(\mathrm{X}_{1}\right)$ dan partisipasi anggota $\left(\mathrm{X}_{2}\right)$ terhadap keberhasilan koperasi $(\mathrm{Y})$ pada
(KOPDIT BINEKAS) sebesar 54,6\%. Sedangkan sisanya $45,4 \%$ dipengaruhi variabel lain yang tidak di masukkan dalam penelitian ini seperti pelayanan, permodalan, pembinaan pemerintah dan kompetensi manajer (Ropke,2003: 170).

\section{Pengujian Model Regresi Secara Simultan ( Uji f )}

Pengujian model regresi secara simultan (Uji f) pada tabel berikut: 
Tabel 10 : Hasil Uii Terhadap Koefisien Regresi Secara Simultan

\begin{tabular}{|c|c|c|c|c|c|}
\hline \multicolumn{6}{|c|}{ ANOVA $^{a}$} \\
\hline & & Sum of Squares & $\mathrm{df}$ & Mean Square & F Sig. \\
\hline \multirow{3}{*}{1} & Regression & 2820.086 & 2 & 1410.043 & $58.378 .000^{\circ}$ \\
\hline & Residual & 2342.904 & 97 & 24.154 & \\
\hline & Total & 5162.990 & 99 & & \\
\hline
\end{tabular}

b. Dependent Variable: keberhasilan koperasi (Y)

Sumber : Data Primer diolah, 2018

Berdasarkan nilai $F$ pada tabel 10 tersebut sebesar 58,378 dan nilai untuk $\alpha=0,05$ dengan derajat kebebasan $=3-1=2$ dan $=100-2$ $1=97$ sebesar 3,09 yang dimana bisa dilihat bahwa lebih besar dari $(58,378>3,09)$ maka ditolak dan diterima artinya dengan tingkat kepercayaan $95 \%$ variabel independen intellectual capital $\left(\mathrm{X}_{1}\right)$ dan partisipasi anggota $\left(\mathrm{X}_{2}\right)$ berpengaruh positif dan signifikan secara simultan (bersama-sama) terhadap keberhasilan koperasi (Y) pada (KOPDIT BINEKAS). Hal ini seperti yang dikemukakan oleh Fathorrazi (2004 : 4) bahwa keberhasilan organisasi koperasi sangat ditentukan oleh kesiapan dan kemampuan anggota koperasi atau keberhasilan koperasi tergantung kualitas para anggota, turut serta anggota koperasi adalah rasa memiliki dan tanggung jawab untuk mengembangkan koperasi, maka dari itu partisipasi anggota berperan penting untuk perkembangan koperasi.

\section{Pengujian Model Regresi Secara Parsial (Uji t)}

Hasil pengujian untuk variabel bebas intellectual capital dan partisipasi anggota terhadap keberhasilan koperasi sebagai berikut:

1. Pengaruh intellectual capital (X1) terhadap keberhasilan koperasi (Y) pada Koperasi Kredit Bina Ekonomi Keluarga Sejahtera (KOPDIT BINEKAS)

Untuk melihat ada atau tidaknya pengaruh intellectual capital (X1 ) terhadap keberhasilan koperasi (Y) secara statistik dapat diuji hipotesisnya sebagai berikut :

$\mathrm{Ho}_{1}: \beta_{1} \leq 0$ : berarti intellectual capital $\left(\mathrm{X}_{1}\right)$ tidak berpengaruh positif dan signifikan terhadap keberhasilan koperasi (Y).

$\mathrm{Ha}_{1}: \beta_{1}>0$ : berarti intellectual capital $\left(\mathrm{X}_{1}\right)$ berpengaruh positif dan signifikan terhadap keberhasilan koperasi (Y).

Berdasarkan tabel 8 tersebut dapat dilihat bahwa pada variabel intellectual capital ( $\mathrm{X}_{1}$ ) sebesar 4,634 dan nilai untuk $\alpha=$ 0,05 dengan derajat kebebasan 100-2$1=97$ sebesar 1,66071 berarti berarti $\mathrm{t}$ hitung $>\mathrm{t}$ tabel $(4,634>1,660)$ dengan nilai signifikasi $0,000<0,05$ maka Ha diterima dan Ho ditolak artinya secara parsial faktor intellectual capital (X1) berpengaruh positif dan signifikan terhadap keberhasilan koperasi (Y) pada Koperasi Kredit Bina Ekonomi Keluarga Sejahtera (KOPDIT BINEKAS).

2. Pengaruh partisipasi anggota $\left(\mathrm{X}_{2}\right)$ terhadap keberhasilan koperasi (Y) pada Koperasi Kredit Bina Ekonomi Keluarga Sejahtera (KOPDIT BINEKAS)

Untuk melihat ada atau tidaknya pengaruh partisipasi anggota $\left(\mathrm{X}_{2}\right)$ terhadap keberhasilan koperasi $(\mathrm{Y})$ secara statistik dapat diuji hipotesisnya sebagai berikut :

$\mathrm{Ho}_{2}: \beta_{2} \leq 0$ : berarti faktor partisipasi anggota $\left(\mathrm{X}_{2}\right)$ tidak berpengaruh positif dan signifikan terhadap keberhasilan kope$\operatorname{rasi}(\mathrm{Y})$.

$\mathrm{Ha}_{2}: \beta_{2}: \geq 0$ : berarti factor partisipasi anggota $\left(\mathrm{X}_{2}\right)$ berpengaruh positif dan signifikan terhadap keberhasilan koperasi (Y). 
Berdasarkan tabel 8 tersebut dapat dilihat bahwa thitung pada variabel partisipasi anggota $\left(\mathrm{X}_{2}\right)$ sebesar 3,869 dan nilai tabel untuk $\alpha=0,05$ dengan derajat kebebasan $100-2-1=97$ sebesar 1,660 berarti $t_{\text {hitung }}>$ $\mathrm{t}_{\text {tabel }}(3,869>1,660)$ dengan nilai signifikasi $0,000<0,05$ maka $\mathrm{H}_{\mathrm{a}}$ diterima dan $\mathrm{H}_{\mathrm{o}}$ ditolak artinya secara parsial faktor partisipasi anggota $\left(\mathrm{X}_{2}\right)$ berpengaruh positif dan signifikan terhadap keberhasilan koperasi (Y) pada Koperasi Kredit Bina Ekonomi Keluarga Sejahtera (KOPDIT BINEKAS).

\section{KESIMPULAN DAN SARAN}

Berdasarkan hasil penelitian, maka dapat disimpulkan :

1. Berdasarkan tanggapan anggota koperasi terhadap intellectual capital, partisipasi anggota dan keberhasilan koperasi :

a. Tanggapan anggota koperasi terhadap intellectual capital menunjukan bahwa penilaian item loyalitas anggota koperasi adalah tertinggi dengan interpretasi sangat baik dan item dengan penilaian terendah adalah tanggung jawab anggota koperasi dengan interpretasi baik.

b. Tanggapan anggota koperasi terhadap partisipasi anggota menunjukan bahwa penilaian item menghadiri (RAT) adalah tertinggi dengan interpretasi sangat baik dan item dengan penilaian terendah adalah turut dalam pengambilan keputusan dengan interpretasi baik.

c. Tanggapan anggota koperasi terhadap keberhasilan koperasi menunjukan bahwa penilaian item koperasi berkontribusi kepada pengusaha kecil dengan membentuk jaringan kerja adalah tertinggi dengan interpretasi sangat tinggi dan item dengan penilaian terendah adalah melalui (SHU) dapat meningkatkan pendapatan dalam memenuhi kebutuhan dengan interpretasi tinggi.

2. Bahwa intellectual capital $\left(\mathrm{X}_{1}\right)$ dan partisipasi anggota $\left(\mathrm{X}_{2}\right)$ secara simultan (bersama-sama) berpengaruh positif dan signifikan terhadap keberhasilan koperasi (Y) pada (KOPDIT BINEKAS).

3. Secara parsial (uji t) pengaruh intellectual capital dan partisipasi anggota terhadap keberhasilan koperasi pada Koperasi Kredit Bina Ekonomi Keluarga Sejahtera (KOPDIT BINEKAS) adalah sebagai berikut :

a. intellectual capital $\left(\mathrm{X}_{1}\right)$ berpengaruh positif dan signifikan terhadap keberhasilan koperasi (Y) pada Koperasi Kredit Bina Ekonomi Keluarga Sejahtera (KOPDIT BINEKAS).

b. partisipasi anggota $\left(\mathrm{X}_{2}\right)$ berpengaruh positif dan signifikan terhadap keberhasilan koperasi (Y) pada Koperasi Kredit Bina Ekonomi Keluarga Sejahtera (KOPDIT BINEKAS).

Adapun saran yang dapat diberikan sebagai berikut :

1. Intellectual capital dan partisipasi anggota yang telah dilaksanakan oleh anggota Koperasi Kredit Bina Ekonomi Keluarga Sejahtera (KOPDIT BINEKAS) harus terus ditingkatkan dengan cara membangun kepercayaan, kebersamaan, komunikasi dua arah, perlakuan adil serta pelatihan yang berkelanjutan kepada anggota terkait intellectual capital. Sedangkan untuk meningkatkan partisipasi anggota dapat dilakukan dengan cara meningkatkan manfaat keanggotaan dan meningkatkan partisipasi kontributif keuangan karena akan berpengaruh terhadap keberhasilan koperasi.

2. Intellectual capital dan partisipasi anggota yang itemnya memiliki penilaian terendah agar

terus diperbaiki, dievaluasi dan ditingkatkan seperti tanggung jawab anggota, ikut serta dalam pengambilan keputusan dan melalui Sisa Hasil Usaha (SHU) dapat meningkatkan pendapatan dalam memenuhi kebutuhan, sehingga hal tersebut akan berpengaruh terhadap 
keberhasilan koperasi.

3. Pihak koperasi sebaiknya mengadakan pelatihan khusus yang wajib diikuti oleh seluruh anggota. Selain itu, anggota yang menjadi delegasi dalam paket pelatihan yang diadakan oleh Pusat Koperasi Kredit wilayah Bogor Banten (PUSKOPDIT BOGOR BANTEN) seharusnya mentransfer ilmu yang didapat kepada seluruh anggota KOPDIT BINEKAS.

4. Bagi yang akan melakukan penelitian lanjutan mengenai sumber daya manusia pada koperasi hendaknya memperdalam kajian terkait faktorfaktor keberhasilan koperasi selain intellectual capital dan partisipasi anggota seperti pelayanan, permodalan, pembinaan pemerintah dan kompetensi manajer sehingga dapat memperluas khasanah keilmuan.

\section{DAFTAR PUSTAKA}

Anoraga dan Widiyanti. 2003. Dinamika Koperasi. Rineka Cipta dan Bina Aksara. Jakarta.

Arikunto, Suharsini. 2010. Prosedur Penelitian Suatu Pendekatan Praktek. Edisi Revisi, PT. Rineka Cipta. Jakarta.

Astuti Yuana, Annisa Anggraeni. 2015. Modal Intelektual dalam Pengembangan Ekonomi Kreatif (Studi Kasus Pada Sentra Kerajinan Sepatu Cibaduyut Bandung). Jurnal Manajemen Indonesia Vol. 15 - No.2. pp 103114

Bontis,Nick and Enz, Jac Fitz. 2002. Intellectual Capital ROI : A Casual Map ofHuman Capital Antecedents and Consequents. Journal of Intellectual Capital. Vol 3 No 3, pp $223-247$

Deputi Bidang Pengembangan Sumber Daya Manusia Kementerian Koperasi dan Usaha Kecil dan Menengah Republik Indonesia. 2010. Buku Saku Perkoperasian.
Dinas KUMKM Propinsi Jawa

Barat, 2017 (http://www.dekop. go.id/berita- informasi/datainformasi/data- koperasi/) diakses pada tanggal 28 Oktober 2017

Dinas Koperasi dan Usaha Kecil 2018 (http://www.diskumkm.jabarprov.go .ig) diakses pada tgl. 05 April 2018.

Fathorrazi, Muhammad 2004, Analisis Komperatif Faktor Partisipasi Anggota,Kinerja Sumber Daya Manusia, Peran Pemerintah Dan Tingkat Keberhasilan Antara Koperasi Multi Usaha Dan Tunggal Usaha Pada Koperasi Susu Sapi Perah Di Jawa Timur, Disertasi, Studi Ilmu Ekonomi, Universitas Airlangga, Surabaya

Gemina, Dwi DKK. 2013. Keunggulan Bersaing Koperasi Berkaitan Dengan Penerapan Intellectual Capital, Manajemen Keanggotaan Dan Partisipasi Anggota (Studi kasus di Koperasi Kota Bogor) Jurnal Manajemen Kewirausahaan vol 15, No 2 pp 191- 204.

Hariyanto Wiwit, Sigit Hermawa. 2010. Pengaruh Intellectual Capital Terhadap Business Performance Dan Competitive Advantage Pada Perusahaan Farmasi Di Jawa Timur. UMSIDA :Malang

Hendar dan Kusnandi. 2009. Ekonomi Koperasi Untuk Perguruan Tinggi Edisi Kedua. FakultasEkonomi Universitas Indonesia. Jakarta.

Hanel, Fred 1985. Basic Aspect of Cooperative Organization. Universitas Padjajaran. Bandung.

Ismail, 2005. Pengaruh Partisipasi Anggota dan Manajemen terhadap Keberhasilan Usaha Koperasi Karyawan Simpan Pinjam di Kota Batam [TESIS] Surabaya : Pascasarjana, Studi ilmu manajemen, Universitas Airlangga. 
Koperasi BINEKAS. 2009. Laporan Pertanggungjawaban Pengurus dan Pengawas.

2013. Laporan Pertanggung jawaban Pengurus dan Pengawas

Meilani, Any. 2002. Hubungan Antara Faktor Anggota dan Partisipasi dengan Keber-hasilan Koperasi. Laporan Penelitian. Lembaga Penelitian Universitas Terbuka.

Pasaribu, R.B.F, Dionysia Kowanda, Sugiharti Binastuti dan Ade Prasetyo, 2014, Pengaruh Intellectual Capital, Bopo, Der Dan Ldr Terhadap Return On Equity Emiten Perbankan Di Bursa Efek Indonesia Periode 2008- 2012, Jurnal Ekonomi dan Bisnis, Vol. 8, No. 3, November. hal: 151-160.

Sartika, Tiktik.2013. Ekonomi Koperasi. Ghalia Indonesia. Bogor

Sugiyono. 2014. Metode Penelitian

Manajemen. Alfabeta. Bandung.

.2017. Metode Penelitian Kuantitatif, Kualitatif dan R\&D. Alfabeta. Bandung

Suharyadi, dan Purwanto S.K.,2009. Statistika Untuk Ekonomi Dan Keuangan Modern, buku II, Edisi 2, Salemba Empat. Jakarta.

Tohar. 2000. Permodalan dan Perkreditan Koperasi. Kanisius. Yogyakarta

Usmara, 2002. Paradigma Baru Sumber Daya Manusia. Amarabooks, Yogyakarta. 